\title{
Evaluation of the variability of citrullus colocynthis (I) schrad as potential biodiesel feedstock: oil content, oil yield and the fatty acid composition
}

\author{
Abdelhamid Benmoumou ${ }^{1}$, and Sä̈ El Madidi ${ }^{*}$ \\ ${ }^{1}$ Biometrics and Bio Resources, Laboratory BVRN, Faculty of Sciences, University Ibn Zohr, Agadir, Morocco
}

\begin{abstract}
Citrullus colocynthis has been garnering interest in recent times as a potential biodiesel feed stockcrop due to its high seed oil content and its natural adaptation to drought The variability seed oil content (OC), Oil yield (kg/ha) (OY) and fatty acid composition were investigated for 12 accessions collected in different localities in Morocco. Analysis of the data revealed high variability among the accessions, with seed oil content ranging between 17.1 and $24.3 \%$ of seed weight and Oil yield from 35.3 to $172.7 \mathrm{~kg} / \mathrm{ha}$. The predominant fatty acid of the seed oil was linoleic acid, C18:2, ranging from 67.0 to $73.0 \%$ of total fatty acids and the average values of unsaturated fatty acids vary between 75.25 and $81.94 \%$.The wide range of variations found in this study for the traits measured offers the possibility of genetic improvement to develop cultivars for biodiesel production compatible with sustainable and ecological agriculture.
\end{abstract}

\section{Introduction}

The increasing awareness of the depletion and shortage of fossil fuel and many global environmental considerations led to the demand of renewable and friendly energy. Citrullus colocynthis (L.) Schrad $(2 \mathrm{n}=22)$, closely related to domesticated watermelon (Citrullus lanatus var. lanatus) [1], is a very drought-tolerant perennial herbaceous species in the Cucurbitaceae family. It is a wild native plant growing in arid areas, widely distributed in the Sahara-Arabian desert in Africa and the Mediterranean region [2,3]. In recent years, the development of new oil seed crops that can be used as alternatives to conventional plants has generated a lot of interest and C. colocynthis is one of the plants that is able to adapt to arid conditions. This plant has a natural adaptation to drought and several studies have reported that this plant has a great potential for adaptation to drought with a tolerance to water deficit $[4,5,6]$. C. colocynthis being an exceptionally hardy plant with a potential for use as biodiesel feedstock $[7,8]$. The plant was also shown to be rich in nutritional value with high protein contents and important minerals as well as edible quality of seed oil [9]. The main objective of this study is the assessment of the variability of 12 accessions of genetic material of Citrullus colocynthis (1) schrad for oil content, oil yield and fatty acid composition of seeds in the perspective that this plant has several arguments to be considered as a candidate potential for biodiesel production.

\section{Materials and Methods}

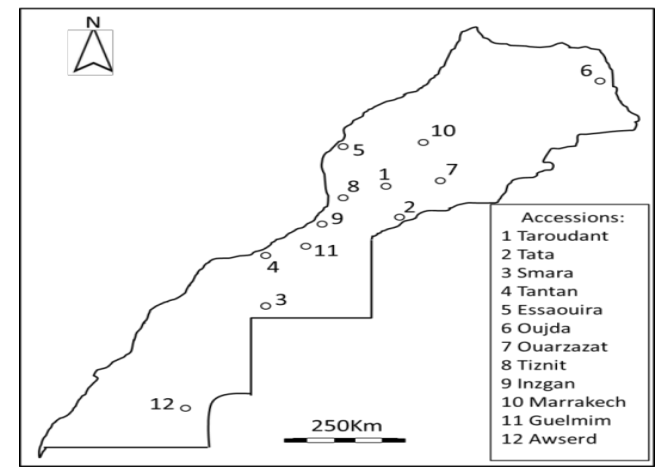

Fig. 1. Origin of accessions of Citrullus colocynthis (L.) Schrad collected in several localities in Morocco

\footnotetext{
*Corresponding author email: $\underline{\text { s.elmadidi@uiz.ac.ma }}$
} 
12 accessions of $C$. colocynthis collected from different regions from Morocco (Fig. 1). The Accessions were compared over two consecutive seasons in field trials presented in a randomized full block plan with three replicates. The measured traits were including seed oil content (OC) and the Oil yield (kg/ha) (OY). Seed oil content is extracted from $400 \mathrm{~g}$ of seeds from each plot with three replicates per accession. For the extraction of the lipid components, the seeds were crushed and then extracted with n-hexane $(200 \mathrm{ml})$ at $40-60{ }^{\circ} \mathrm{C}$ in a soxhlet apparatus. The total extraction time was 6 hours for each repetition. The composition of the oil in fatty acids was determined by Chromatography coupled with Mass Spectrometry. Statistics analysis was carried out using computer software SAS version 9.3 (SAS Institute Inc. 2010)

\section{Results}

The oil yield varies between 35.27 and $171.70 \mathrm{~kg} /$ hectare while the seed oil content (OC) shows the lowest CV and the minimum and maximum are respectively 17.1 and $24.3 \%$ (Table 1 ).

Table 1. Descriptive statistics of OC and OY

\begin{tabular}{|l|c|c|c|c|c|c|}
\hline & Mean & Min & Max & SD & CV & SE \\
\hline OC (\%) & 21.40 & 17.100 & 24.29 & 1.63 & 7.65 & 0.19 \\
\hline OY (Kg/ha) & 89.84 & 35.268 & 171.70 & 34.99 & 38.95 & 4.12 \\
\hline
\end{tabular}

OC : seed oil content, OY : Oil yield (kg/ha), Min : Minimum, Max : Maximum, SD : standard deviation: CV : coefficient of variation and $\mathrm{SE}:$ standard error.

The comparison of accessions means showed highly significant differences (Table 2). For the OC, average values are grouped into 5 homogeneous groups and ranged from $19.25 \pm 1.65$ (accession 6) to $22.96 \pm 0.67$ (accession 11). For oil yield, the average values are arranged also in 5 homogeneous groups and vary between $61.21 \pm 13.31 \mathrm{~kg} / \mathrm{ha}(\mathrm{accession}$ 10) and $146.97 \pm 30.08 \mathrm{~kg} / \mathrm{ha}$ (accession 11 ).

Table 2. Variability of OC and OY according to the accessions

\begin{tabular}{|c|c|c|c|c|c|c|c|c|c|c|c|c|}
\hline A & A 1 & A2 & A3 & A4 & A5 & A6 & A7 & A8 & A9 & A 10 & A11 & A12 \\
\hline $\mathrm{O}$ & & & & & & & & & & & & \\
\hline C & bc & b & e & & $\begin{array}{c} \pm 1.52 \\
\mathrm{bc}\end{array}$ & $\begin{array}{c}1.65 \\
\mathrm{a}\end{array}$ & & & & & & \\
\hline & & & & & & & & & & & & \\
\hline Y & & & & $7 \mathrm{ab}$ & & $\begin{array}{c} \pm 4.56 \\
\text { abc }\end{array}$ & & & $8 \mathrm{bcd}$ & $\begin{array}{c} \pm 13.3 \\
1 \mathrm{a}\end{array}$ & & cde \\
\hline
\end{tabular}

OC : seed oil content, OY : Oil yield (kg/ha). a,b,c,d : means within columns with different superscript are significantly different (p $<0,01)$

The analysis of the composition of the oils of Citrullus colocynthis by gas chromatography shows that the oil of the colocynth, taking into account all the accessions, is mainly composed of fatty acids: linoleic (C18: 2), acid oleic (C18: 1), stearic acid (C18: 0) and palmitic acid (C16: 0) with 66\%, 13\%, 10\% and 10\% respectively, the content of other fatty acids is less than $1 \%$ (Fig. 2).

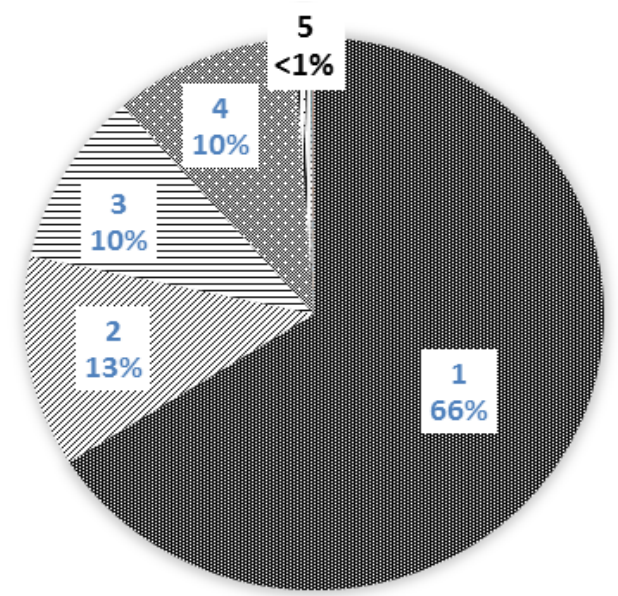

Fig. 2. Average fatty acid composition of seeds of Citrullus colocynthis : $1:(\mathrm{C} 18: 2), 2:(\mathrm{C} 18: 1), 3:(\mathrm{C} 18: 0), 4:(\mathrm{C} 16: 0)$ and 5 : others 
The analysis of the composition of the oils of Citrullus colocynthis by gas chromatography shows that the oil of the colocynth, taking into account all the accessions, is mainly composed of fatty acids: linoleic (C18: 2), acid oleic (C18: 1), stearic acid (C18:0) and palmitic acid (C16:0) with 66\%, 13\%, 10\% and 10\% respectively, the content of other fatty acids is less than $1 \%$ (Fig. 2).

Table 3. Variability between the accessions depending on the most important fatty acids

\begin{tabular}{|l|c|c|c|c|c|c|}
\hline & C16.0 & C18.0 & C18.1 & C18.2 & UFA & UFA/SFA \\
\hline A1 & $11.72 \mathrm{f}$ & $12.37 \mathrm{~d}$ & $13.87 \mathrm{bc}$ & $60.57 \mathrm{a}$ & $75.25 \mathrm{a}$ & $3.05 \mathrm{a}$ \\
\hline A2 & $9.46 \mathrm{abcd}$ & $11.30 \mathrm{bcd}$ & $11.81 \mathrm{ab}$ & $65.98 \mathrm{abc}$ & $78.61 \mathrm{abc}$ & $3.685 \mathrm{abc}$ \\
\hline A3 & $8.82 \mathrm{ab}$ & $9.88 \mathrm{abcd}$ & $11.48 \mathrm{ab}$ & $68.29 \mathrm{c}$ & $80.65 \mathrm{bc}$ & $4.22 \mathrm{~cd}$ \\
\hline A4 & $9.82 \mathrm{bcde}$ & $9.37 \mathrm{abc}$ & $12.84 \mathrm{abc}$ & $66.58 \mathrm{bc}$ & $80.20 \mathrm{bc}$ & $4.07 \mathrm{bcd}$ \\
\hline A5 & $10.84 \mathrm{cdef}$ & $11.43 \mathrm{bcd}$ & $15.20 \mathrm{c}$ & $61.16 \mathrm{ab}$ & $77.07 \mathrm{ab}$ & $3.36 \mathrm{ab}$ \\
\hline A6 & $9.51 \mathrm{abcd}$ & $9.49 \mathrm{abc}$ & $11.13 \mathrm{ab}$ & $68.30 \mathrm{c}$ & $80.24 \mathrm{bc}$ & $4.18 \mathrm{bcd}$ \\
\hline A7 & $9.15 \mathrm{abc}$ & $9.53 \mathrm{abc}$ & $13.17 \mathrm{abc}$ & $66.74 \mathrm{bc}$ & $80.67 \mathrm{bc}$ & $4.19 \mathrm{bcd}$ \\
\hline A8 & $11.16 \mathrm{def}$ & $9.68 \mathrm{abc}$ & $11.28 \mathrm{ab}$ & $66.43 \mathrm{bc}$ & $78.50 \mathrm{abc}$ & $3.69 \mathrm{abc}$ \\
\hline A9 & $8.04 \mathrm{a}$ & $9.43 \mathrm{abc}$ & $11.50 \mathrm{ab}$ & $69.87 \mathrm{c}$ & $81.94 \mathrm{c}$ & $4.54 \mathrm{~d}$ \\
\hline A10 & $11.96 \mathrm{f}$ & $8.89 \mathrm{ab}$ & $11.77 \mathrm{ab}$ & $65.85 \mathrm{abc}$ & $78.47 \mathrm{abc}$ & $3.67 \mathrm{abc}$ \\
\hline A11 & $8.79 \mathrm{ab}$ & $8.57 \mathrm{a}$ & $10.45 \mathrm{a}$ & $70.86 \mathrm{c}$ & $82 \mathrm{c}$ & $4.56 \mathrm{~d}$ \\
\hline A12 & $11.33 \mathrm{ef}$ & $12.01 \mathrm{~cd}$ & $13.39 \mathrm{bc}$ & $61.63 \mathrm{ab}$ & $75.95 \mathrm{a}$ & $3.19 \mathrm{a}$ \\
\hline
\end{tabular}

a,b,c,d : Means within columns with different superscript are significantly different $(\mathrm{p}<0,05)$

The varability analysis of the fatty acid composition showed that the degree of unsaturation was over $75 \%$ and ranging from 75.25 to $82 \%$. Linoleic acid was found to be the dominant fatty acid, ranging from 67.0 to $73.0 \%$, followed by oleic, ranging from 10.45 to $15.20 \%$, stearic acide $(8.57-12.37 \%$ ) and palmitic acide $(8.04-11.72 \%$,) (Table 3$)$. The statistical analysis shows significant differences $(p$-value $<0.05)$ between the accessions studied for all the fatty acids analysed. Table 3 presents the results of the comparison between the accessions for the most dominant fatty acids. For the linoleic fatty acid (C18.2), the mean values are separated into 4 groups with the lowest value observed in accession 1 (60.57) while the highest value is obtained for accession 11 (70.86). These results also show that the average values of unsaturated fatty acids (UFA) vary between 75.25\% (accession 1) and 81.94 (accession 9). Regarding the calculated ratio between unsaturated and saturated fatty acids (UFA / SFA), it reaches 4.5 for the accessions A9 and A11, the lowest values of this ratio are recorded for accessions A1 and A12 with 3.04 and 3.18 respectively.

\section{Conclusions and Discussion}

The analysis of the average fatty acid composition shows that the major acids are linoleic acid followed by oleic acid (C18: 1), stearic acid (C18: 0) and palmitic acid (C16: 0) with 66, 13, 10 and 10\% respectively. These fatty acid composition are in agreement with the results of other studies $[7,10,11,12]$.

The statistical analysis of the fatty acid contents of the oils of the different accessions reveals significant differences between the studied accessions. The proportions of linoleic acid (C18: 2) vary between $60.57 \%$ and $70.86 \%$, the highest value was recorded in accession A11 with a percentage of $70.86 \%$. This variability may be due to the influence of several factors. A study related to variations in the content of linoleic acid, the authors report that the synthesis of this fatty acid is influenced by temperature and it is synthesized in large quantities at lower temperatures due to the sensitivity of an enzyme involved in its synthesis [13]. The examination of the ratio between unsaturated and saturated fatty acids shows that the maximum value is 4.5 observed in accessions A9 and A11, on the other hand the minimum value which is 3.04 is recorded in A1. Ratios similar to those in this study have been reported by Nehdi et al. [12] and by Milovanovic \& Picuric [11].

The oil yield values obtained in this study under semi-arid conditions without any fertilizer, under conditions of limited irrigation and with a low density $\left(1\right.$ plant per $\left.\mathrm{m}^{2}\right)$, remain relatively low compared to those potentially obtained under optimal growing conditions and optimal planting density. The oil yield values obtained in this study under semi-arid conditions without any fertilizer and under conditions of limited irrigation, remain relatively low compared to those potentially obtained under optimal growing conditions. The authors of a study conducted on the production of Citrullus colocynthis, reported that production can reach 1000 to $1175 \mathrm{~L} /$ ha of colocynth vegetable oil in rainy conditions [14]. With plant density of four plants per $\mathrm{m}^{2}$, the extrapolated annual oil yield among the accessions of Citrullus colocynthis ranged from 0.07 and 3.44 tons / ha with an overall mean of 0.98 ton / ha [15]. The evaluation of seed and oil yields of 28 accessions grown under suitable irrigation and fertilization conditions allowed an estimation of oil yield ranging from 250 to $400 \mathrm{~L} /$ ha based on seed yield [16]. All the results of this study and also those of similar studies, allow us to think that this plant has a great potential to be used for grain production for oil extraction, especially under difficult conditions on arid and semi-arid lands and the exploitation of the natural variability could be used for the selection of accessions that have good oil yields in limited growing conditions and in 
marginal lands especially taking into account that the heritability and genotypics advances estimates for traits involved in seed and oil yield are moderate to high [17].

\section{Acknowledgements}

This work has received financial support from Ibn Zohr University and the valuable assistance of the management and technicians of the Sidi Bibi experimental center for the installation and monitoring of the field experience.

\section{References}

1. G. Chomicki, S. S. Renner, Watermelon origin solved with molecular phylogenetics including L innaean material: another example of museomics, New Phytologist 205(2), 526-532 (2015)

2. Y. Si, F. Dane, A. Rashotte, K. Kang, N. K. SinghCloning and expression analysis of the Ccrboh gene encoding respiratory burst oxidase in Citrullus colocynthis and grafting onto Citrullus lanatus (watermelon), Exp Bot $\mathbf{6 1}$ (6), 1635-1642 (2010)

3. Z. Wang, H. Hu, L.R. Goertzen, J.S. McElroy, F. Dane, Analysis of the Citrullus colocynthis Transcriptome during Water Deficit Stress, PLOS ONE 9(8), 1-12 (2014)

4. A. Hassan, R. Younis, M. Rashed, , , F. Eldomyati, N. Rashed, Molecular markers associated with drought tolerance in Citrullus colocynthis, Egyptian Journal of Genetics and Cytology 41(2), 311-325 (2012).

5. S. El Madidi, A. BenMoumou, and F. Hakimi, Variability in the Response of Citrullus Colocynthis (L.) to Water Deficiency Stresses, In Euro-Mediterranean Conference for Environmental Integration, Springer, Cham, 13611362 (2017)

6. K. S. Verma, S. ul Haq, S. Kachhwaha, S. L. Kothari, RAPD and ISSR marker assessment of genetic diversity in Citrullus colocynthis (L.) Schrad: a unique source of germplasm highly adapted to drought and hightemperature stress, 3 Biotech. 7(5), 1-24 (2017)

7. S. Giwa, L. C. Abdullah, N. M. Adam, Investigating "Egusi"(Citrullus colocynthis L.) seed oil as potential biodiesel feedstock, Energies 3(4), 607-618 (2010)

8. E. I. Bello, A. Makanju, Performance evaluation of Egunsi melon (Citrullus colocynthis L.) seeds oil biodiesel, Journal of Emerging Trends in Engineering and Applied Sciences 2(5), 741-745, (2011)

9. A. I. Hussain, H. A. Rathore, M. Z. A. Sattar, S. A. S. Chatha, S. D. Sarker, A. H. Gilani, Citrullus colocynthis (L.) Schrad (bitter apple fruit): A review of its phytochemistry, pharmacology, traditional uses and nutritional potential, J. Ethnopharmacol 155, 54-66 (2014)

10. S.B. Chavan, R.R. Kumbhar, Y.C. Sharma, Transesterification of Citrullus colocynthis (Thumba) oil: Optimization for biodiesel production, Adv. Appl. Sci.Res. 5(3), 10-20 (2014)

11. M. Milovanovic, K. Picuric, Characteristics and composition of melon seed oil, Journal of Agricultural Sciences 50(1), 41-47 (2005)

12. I. A. Nehdi, H. Sbihi, C. P. Tan, S. I. Al-Resayes, Evaluation and characterisation of Citrullus colocynthis (L.) Schrad seed oil: Comparison with Helianthus annuus (sunflower) seed oil, Food chemistry 136(2), 348-353 (2013)

13. M. Mancha, C. Sarmiento, R. Garcés, Acyl turnover in triacylglycerols. Its role in the regulation by temperature of the 18: 1/18: 2 ratio in sunflower seeds. In Plant Lipid Metabolism, Springer, Dordrecht (1995)

14. R.S. Mertia, I.C. Gupta, Cultivate the colocynth in waste lands, Indian Horticulture, India (1994)

15. K. Menon, N. Sood, N. K. Rao, Study of morpho-agronomic diversity and oil content in desert gourd ('Citrullus colocynthis' (L.) Schrad.), Australian Journal of Crop Science 10(7), 1000 (2016)

16. Z. Yaniv, E. Shabelsky, D. Schafferman, Colocynth: potential arid land oilseed from an ancient cucurbit, Perspectives on New Crops and New Uses, ASHS Press, Alexandria, Virginia (1999)

17. S. El Madidi, A. BenMoumou, Genotypic Variation of Seed Oil Content in Twelve Genotypes of Citrullus colocynthis from Morocco, Current Applied Science and Technology 20, 117-123 (2020) 